\title{
Do poor people in the poorer states pay more for healthcare in India?
}

\author{
Anjali Dash ${ }^{1^{*}}$ and Sanjay K. Mohanty ${ }^{2}$
}

\begin{abstract}
Background: Rising health spending is associated with high out-of-pocket expenditure (OOPE), catastrophic health spending (CHS), increasing poverty, and impoverishment. Though studies have examined poverty and impoverishment effect of health spending in India, there is limited research on the regional patterns of health spending by type of health centers. This paper tests the hypothesis that the poor people from the poorer states of India pay significantly more for hospitalization in public health centers than those in the richer states of India.

Methods: Data from the Social Consumption of Health Survey (71st round, 2014), carried out by the National Sample Survey (NSS) is used in the analyses. Descriptive statistics, log-linear regression model and tobit model were used to examine the determinants and variations in health spending.

Results: Inter-state variations in the utilization of public health services and the OOPE on hospitalization are high in India. States with high levels of poverty make higher use of the public health centers and yet incur high OOPE. In 2014, the mean OOPE per episode of hospitalization in public health centers in India was ₹5688 and ₹4264 for the economically poor households. It was lowest in the economically developed state of Tamil Nadu and highest in the economically poorer state of Bihar. The OOPE per episode of hospitalization in public health centers among the poor in the poorer states was at least twice that in Tamil Nadu. Among the poor using public health centers, the share of direct cost account 24\% in Tamil Nadu compared to over $80 \%$ in Bihar, Odisha and other poorer states. Adjusting for socio-economic correlates, the cost of hospitalization per episode (CHPE) among the poor using public health centers was 51\% lower than for the non-poor using private health centers in India.
\end{abstract}

Conclusion: The poor people in the poorer states in India pay significantly more to avail hospitalization in public health centers than those in the developed states. Provision of free medicines, surgery and free diagnostic tests in public health centers may reduce the high OOPE and medical poverty in India.

Keywords: Public health, Hospitalization, Out-of-pocket expenditure, Financial protection, Poverty, India

\section{Background}

Over a hundred million people are pushed into poverty annually due to health spending, and the impact of health spending on poverty is high in low-resource settings [1-5]. About 97 million people were impoverished due to spending on health care in 2010 [1]. Globally, an estimated 588 million (9.7\%) people had incurred CHS in 2000 and it has increased to 808 million (11.7\%) in 2010 [5]. Evidence from 14 low and middle income countries of Asia suggests that poorer countries, with low social protection, rely heavily on direct payments

\footnotetext{
* Correspondence: dash86.eco@gmail.com

${ }^{1}$ International Institute for Population Sciences, Govandi Station Road,

Deonar, Mumbai, Maharashtra 400088, India

Full list of author information is available at the end of the article
}

and the poverty impact of health spending is high $[1,3]$. In 2014, the OOPE on health, defined as health expenditure net of reimbursement, was the highest in Comoros (76\%), followed by Yemen and lowest (less than 1\%) in New Zealand followed by Kiribati [2]. High OOPE is associated with increasing non-communicable diseases (NCDs), increase in the share and the size of the elderly population, increasing cost of health care, increasing income levels, low coverage of health insurance, advancements in medical technology and low public spending on health care [6-9]. Besides, the opportunity cost of medical care is very high in developing countries [10-14]. High expenditure on health adds to unequal access in health care utilization across regions and socio-

(c) The Author(s). 2019 Open Access This article is distributed under the terms of the Creative Commons Attribution 4.0 International License (http://creativecommons.org/licenses/by/4.0/), which permits unrestricted use, distribution, and 
economic groups $[15,16]$. Affordable health services are a fundamental goal of welfare states, and protecting households from CHS is a key monitoring indicator of the sustainable development goals (SDGs) $[2,17,18]$.

The high OOPE on health care affects the poor and the vulnerable the most, and has drawn considerable attention from researchers and policy makers in developing countries. Protecting people from increasing health care costs is also a priority developmnet agenda worldwide. However, a sizeable proportion of the population does not seek health care due to increasing health care costs. The high OOPE in developing countries leads to a reduction in the consumption of non-food goods [19], and increases the incidence of untreated morbidity, particularly among the rural, poor, female-headed and elderly households $[6,20]$. Studies suggests that medical poverty is high among households with chronic NCDs, and due to high share of medicines on total cost of hospitalization [21-24]. Owing to heavy reliance on direct OOPE and low financial protection by government health systems $[1,4]$ the poor often deprived of access to health care [25-27]. Since the AlmaAta declaration in 1978, there has been a global effort to provide accessible and affordable quality of health care services through universal health coverage (UHC) [28]. Evidence shows that UHC has helped reduce financial hardships in many developing countries but not progressive in India $[29,30]$.

\section{The Indian scenario}

India's health system is characterized by the co-existence of public and private health care providers. Public health facilities are provided by the central government, the state governments, and local bodies [17, 31]. Public health centers provide low cost care, are generally overcrowded, and largely used by the poor. Despite the low cost of health care in public health facilities, the poor households incur a high CHS and bear a higher burden of diseases [31-34]. About $71.1 \%$ of the health spending in 2004 and $67.74 \%$ in 2014 was met by households [35] Public health spending in India was about $1 \%$ of gross domestic product (GDP), lower than that in many low income countries. Evidence shows that medical poverty owing to high OOPE increased from 32.5 million in 1999-2000 to 50.6 million in 2011-12 [25, 36-38]. Every year, 3.5 to $6.2 \%$ of the population of India was pushed into poverty due to high OOPE $[3,25,39]$. The impoverishment effect of hospitalization cases is also high [16, 40]. Similarly, about $23.4 \%$ households incurred CHS during 2011-12 [27]. The national average in health spending conceals large variations across the states of India. The high burden of health spending in India affects the poorer states, the poorer regions/districts within the states, and the poor considerably more than the richer counterparts [21, 40-42]. Evidence shows that despite an increase in insurance coverage financial risk protection has not been reduced [43-45].

Earlier studies in India found large inter-state variations in the per capita health spending, OOPE, CHS and impoverishment effect of health spending across states, residence, gender, and economic groups [27, 41, 46, 47]. Some empirical studies focused on expenditure on outpatient by type of health care providers $[9,48]$. Though studies have examined on the disparities in health outcomes, access, coverage, and quality of care [17, 49-51], there are limited number of studies on inter-state variations in health spending in India [41, 52]. Moreover, none of the studies have focused on inter-state variation in health spending with respect to type of health centers and poverty. In this context the main objective of this paper is to examine the OOPE on hospitalization in public and private health centers by level of poverty across the states of India. It seeks to answer the following research questions: Do poor people in the poorer states pay more for hospitalization in public health centers? What are the factors leading to high payments at public health centers in the poorer states? It tests the hypothesis that the poor from the poorer states of India pay significantly more on hospitalization in public health centers than the poor in the developed states in India.

\section{Methods \\ Data}

This study used unit data of Social Consumption on Health, schedule 25.0 of the 71st round (2014), collected by the NSS, Government of India from January to June 2014. The NSS, under the Ministry of Statistics and Program Implementation, has been conducting nationwide large sample surveys since its inception in 1950. It collected information on a wide range of socio-economic issues such as consumption, employment and unemployment, morbidity and health care, education, migration etc. in its various rounds. The first comprehensive morbidity and health care survey was conducted in the 42nd round, July 1986-June 1987 . Since then, three rounds of health surveys (52nd, 60th and 71st) have been conducted. The instruments and sampling coverage have been revised over time. The 60th round conducted in 2004 and the 71st round conducted in 2014 are the latest two rounds of health surveys. Details methodology and findings of the 71st round are available in the report [53]. Owing to increasing demand, the NSS conducted a health survey in its 75th round (July 2017-June 2018) and the data/report is yet to be released. The 71st round unit level data is available from Indian Council of Social Science Research (ICSSR) data repository and could be accessed upon a data request through http://www.icssrdataservice.in/datarepository/index.php/catalog/107. 
The 71st round survey provided comprehensive information on the type of treatment, disease pattern, type of health centers (public and private), the amount reimbursed, source of financing, etc. based on a 365 day reference period of hospitalization and a 15 day reference period for out-patient care. In this study, we have used episode of hospitalization in a 365 day reference period as the unit of analyses. The survey covered all 36 states, including the union territories of India. A total of 65,932 households (335,499 individuals of which 333,104 survived and 2,395 death cases) were successfully interviewed. We retain the survival and death cases for the analysis, as health spending on individuals who eventually died was significantly higher than that on individuals who survived [54].

To understand the supply side factors of the health sector, we have used the government reports published by the Ministry of Health and Family Welfare (MoHFW), Government of India and the 4th round of District Level Households and Facility Survey (DLHS-4). The DLHS-4 was carried out by the International Institute for Population Sciences (IIPS) during 2012-13. It was the first ever survey in the Indian context that provides information on supply side variables. The district level estimates are available for public use and unit data could be accessed upon request through http://rchiips.org/DLHS-4.html.The survey covered in four tiers of health facilities: sub center (SC), primary health center (PHC), community health center $(\mathrm{CHC})$ and district hospital (DH). The survey provided information on human resources (number of doctors and paramedical staffs), accessibility of health facilities (distance from villages to $\mathrm{PHC}$ ) and related information at the facility level [55]. We have used the following variables at the state level: shortfall of public health centers such as $\mathrm{SC}, \mathrm{PHC}, \mathrm{CHC}, \mathrm{DH}$, shortfall of a medical doctor, shortfall of paramedical staffs, shortfall of bed, density of bed per one lakh population and health workers per 1000 population At the district level, we have computed the shortfall of doctor, nurse and bed. We prefer to use the shortfall in health infrastructure, manpower and distance at the PHC level due to data constraints. Though information on district hospitals was available in DLHS-4, there was one district hospital per district and hence no variation could be shown.

In the present study, we focused on 19 major states along with Delhi, where the number of hospitalized cases was 300 and more in each public and private health care center. We have used state-specific poverty lines by rural and urban areas, as suggested by the Rangarajan committee to identify the poor and the non-poor [56]. The state specific poverty line is a standard measure of comparison of the poverty level and the poverty cut-off is higher in richer states than in the poorer states. Tamil Nadu was used as a reference state as it had low OOPE on hospitalization in public health centers.

\section{Outcome variable}

A composite variable combining type of health centers (public and private) and poverty (poor and non-poor) was computed and categorized into four distinct groups. These are individuals belonging to (i) poor households and using public health centers (ii) poor households and using private health centers (iii) nonpoor households and using the public health centers and (iv) non-poor households and using private health centers. The OOPE on hospitalization was computed for each of these four categories across the states of India. Cost of hospitalization per episode (CHPE) is used as an outcome variable in multivariate analyses and reimbursement was used as an independent variable in the regression model.

\section{Independent variables}

The covariates used in the analysis were: residence (rural, urban), religion (Hindu, Muslim, Others), caste (schedule caste/schedule tribe (SC/ST), other backward classes (OBC), others), sex (male, female), poverty and health care utilization (poor using public health centers, poor using private health centers, non-poor using public health centers, non-poor using private health centers), age $(<=14$, $15-59,>=60$ ), surgery (not received, free or partly free, on payment), medicine (not received, free or partly free, on payment), $x$-ray (not received, free or partly free, on payment), diagnostic (not received, free or partly free, on payment), and reimbursement of health expenditure (no insurance, insurance but did not benefit, benefited from insurance), disease (cancer, bone disease, diabetes, fever, high blood pressure, accident, jaundice/respiratory, heart, eye, tuberculosis, blood disease, neurological, others).

\section{Statistical analysis}

Descriptive statistics, bivariate and multivariate analyses were used. Log-linear regression model and Tobit regression model were used in this analysis. Log linear regression model used as CHPE was a continuous variable and skewed. The general regression model used for the study is defined in eq. 1.

$$
\begin{aligned}
\text { Ln }(\text { CHPE }) & =\alpha+\beta_{1} \text { res }_{i}+\beta_{2} \text { age }_{i}+\beta_{3} \text { sex }_{i}+\beta_{4} \text { religion }_{i} \\
& +\beta_{5} \text { caste }_{i}+\beta_{6} \text { pov_hos }_{i}+\beta_{7} \text { medicine }_{i} \\
& +\beta_{8} \text { surgery }_{i}+\quad \beta_{9} \text { xray }_{i}+\beta_{10} \text { diagnostic }_{i} \\
& +\beta_{11} \text { insurance }_{i}+\beta_{12} \text { diseases }_{i}+e_{i}
\end{aligned}
$$

where $\alpha$ is the intercept, subscript $i$ is used for episode of hospitalization, res is residence, age is age of patients, pov_hos is composite variable of poverty and type of health centers, medicine is the services of medicine, 
surgery is the services of surgery, $x$-ray is the services of $\mathrm{x}$-ray, diagnostic is the services of diagnostic tests, insurance is the benefit or status of insurance, and diseases is the broad disease classification. The analyses are conducted by using sampling weights to secure representativeness of the estimation.

\section{Robustness analysis}

We have used the Tobit model as an alternate model to check the robustness of the main results. The Model specification remains the same as of eq. 1 .

The Tobit model is defined as:

$$
\mathrm{CHPE}_{\mathrm{i}}=\beta_{\mathrm{i}} \mathrm{X}_{\mathrm{i}}^{\prime}+\mathrm{e}_{\mathrm{i}}
$$

where, $\mathrm{CHPE}_{\mathrm{i}}$ is the cost of hospitalization per episode in Indian rupees (₹) and $X_{i}^{\prime}$ is vectors of independent variables. The set of independent variables are similar as of eq. $1 . \beta_{i}$ is the regression coefficient, and $e_{i}$ error terms. Results are presented as marginal effects and estimates are provided for India, Bihar and Tamil Nadu.

\section{Results}

Table 1 presents the descriptive statistics of the sample households and individuals covered in the survey. Among all households surveyed, $12 \%$ of the households were poor and using public health centers, $6 \%$ were poor and using private health centers, $19 \%$ were non-poor and using public health centers and $23 \%$ were non-poor and using private health centers and $41 \%$ did not seek hospitalization care. About $60 \%$ of the households, one member or more was hospitalized. In 2014, the mean age of hospitalization was 34 years, the monthly per capita expenditure (MPCE) of the households was ₹ 1625 , and it was the lowest among the poorer households who were hospitalized in public health centers (₹807) and the highest among the non-poor households who were hospitalized in private health centers (₹2245).
Inter-state variations in the utilization of public and private health centers for hospitalization care

Figure 1 presents the percentage distribution of hospitalization in public and private health centers in the states of India. The utilization of health services in public health centers was the highest in Assam (87\%), followed by Odisha (80\%), West Bengal (70\%), Rajasthan (64\%), Madhya Pradesh (62\%), and Bihar (55\%). On the other hand, the utilization of health services in private health centers was 74\% each in Andhra Pradesh, Maharashtra and Gujarat. Barring Uttar Pradesh and Andhra Pradesh, states that were economically better-off used more of the private health centers, while poorer states used more of the public health centers.

Appendix 1 of the Additional file 1 presents hospitalization by disease and type of health centers across the states of India. Among those hospitalized in public health centers, about $45 \%$ each were hospitalized for NCDs and communicable diseases (CDs). In the case of private health centers, two-thirds of the hospitalized cases were for NCDs and about one-fifth of the cases were for CDs. The state pattern suggests that the majority of the hospitalized cases in private health centers were for NCDs. In Kerala, about $68 \%$ of the hospitalized cases in public health centers were for NCDs while it was $21 \%$ in Jharkhand followed by $23 \%$ in Bihar. This pattern was opposite in the case of CDs. More than half of the hospitalization cases in private health centers across all the states was for NCDs.

\section{Poverty and hospitalization in the states of India}

Figure 2 presents the scatter plot of the percentage of population living below the poverty line and the percentage of the poor hospitalized in public health centers. Among the 19 states of India, the poverty level was over $40 \%$ in Chhattisgarh, Odisha, Madhya Pradesh, and Bihar and less than $15 \%$ in the states of Kerala, Delhi, Punjab, and Andhra Pradesh. In general, the poor belonging to the states with a higher poverty level were

Table 1 Monthly per capita consumption expenditure, mean age and percentage urban by poverty and type of health centers in India, 2014

\begin{tabular}{|c|c|c|c|c|c|}
\hline Parameters & $\begin{array}{l}\text { Poor using public } \\
\text { health centers }\end{array}$ & $\begin{array}{l}\text { Poor using private } \\
\text { health centers }\end{array}$ & $\begin{array}{l}\text { Non-poor using public } \\
\text { health centers }\end{array}$ & $\begin{array}{l}\text { Non-poor using private } \\
\text { health centers }\end{array}$ & India \\
\hline $\begin{array}{l}\text { Total Number of household } \\
\text { surveyed }\end{array}$ & 7,642 & 4,051 & 12,343 & 14,939 & 65932 \\
\hline $\begin{array}{l}\text { Total number of } \\
\text { hospitalized case }\end{array}$ & 10,033 & 6,278 & 17,406 & 23,739 & $\begin{array}{l}57 \\
456\end{array}$ \\
\hline$\%$ residing in urban areas ${ }^{\mathrm{a}}$ & 23.97 & 35.12 & 20.68 & 37.46 & 29.98 \\
\hline Mean age ${ }^{a}$ & 31 & 32 & 34 & 37 & 34 \\
\hline MPCE (in Indian rupees) ${ }^{a}$ & 807 & 880 & 1654 & 2245 & 1625 \\
\hline
\end{tabular}

${ }^{a}$ t-test shows significant differences in mean age and MPCE of poor using public health centers and each of the three other groups. Chi-square test shows significant differences in percentage urban across groups 


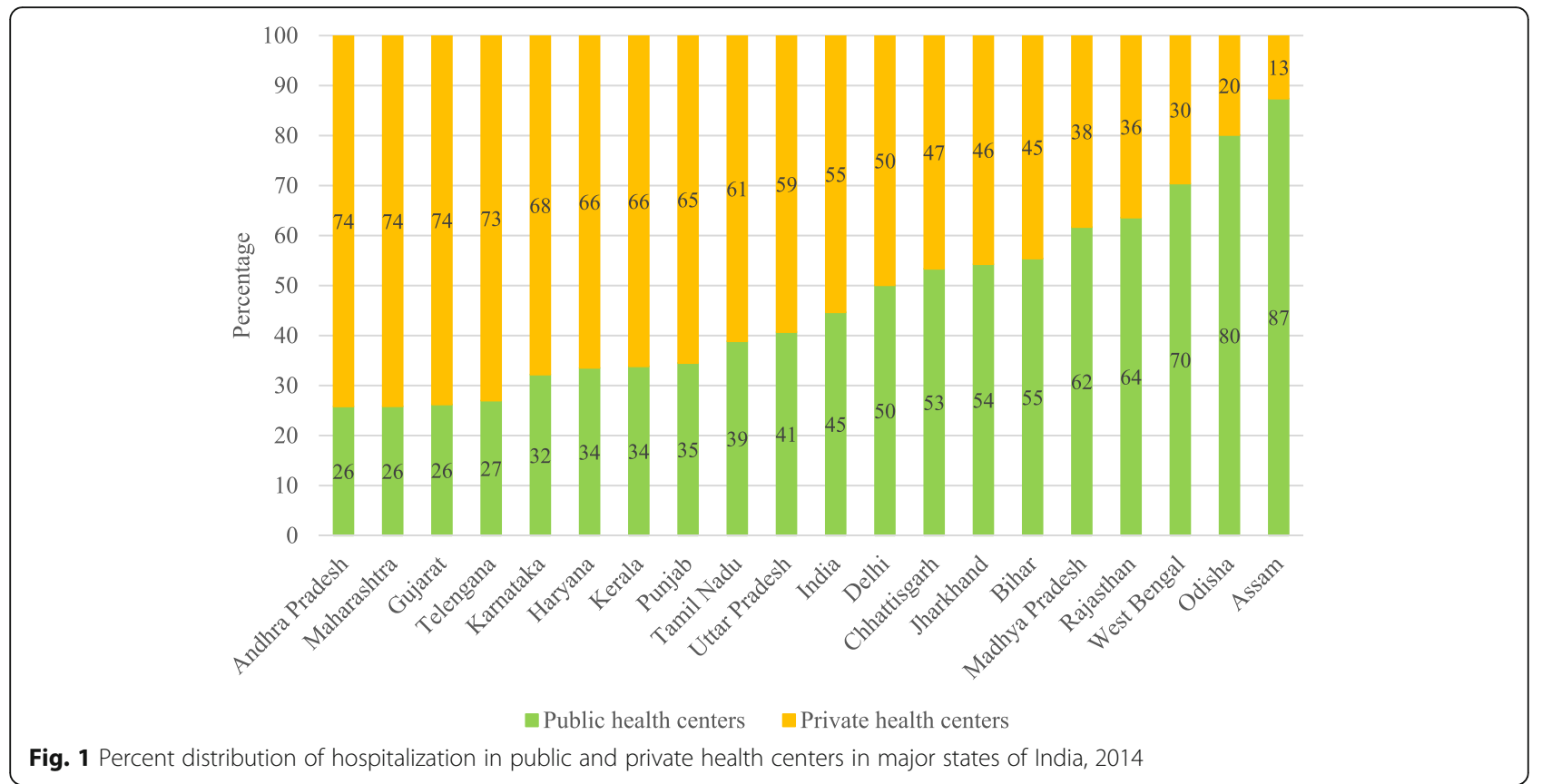

using more health services from the public health centers for hospitalization care.

Table 2 presents the utilization of public health centers among the poor and non-poor in states of India. The use of public health centers was higher among poor than non-poor in each of the state of India. In India, about $61 \%$ of the poor were using public health centers compared to $40 \%$ of the non-poor. The proportion of poor utilizing public health centers for hospitalization was highest in Assam followed by Odisha, Delhi, West Bengal and Rajasthan. It was low in Gujarat, Haryana, and Telangana.

Figure 3 presents the inter-state variations in hospitalization by public and private health centers and poverty level in India. Among those hospitalized, 16\% belonged to poor households and used public health

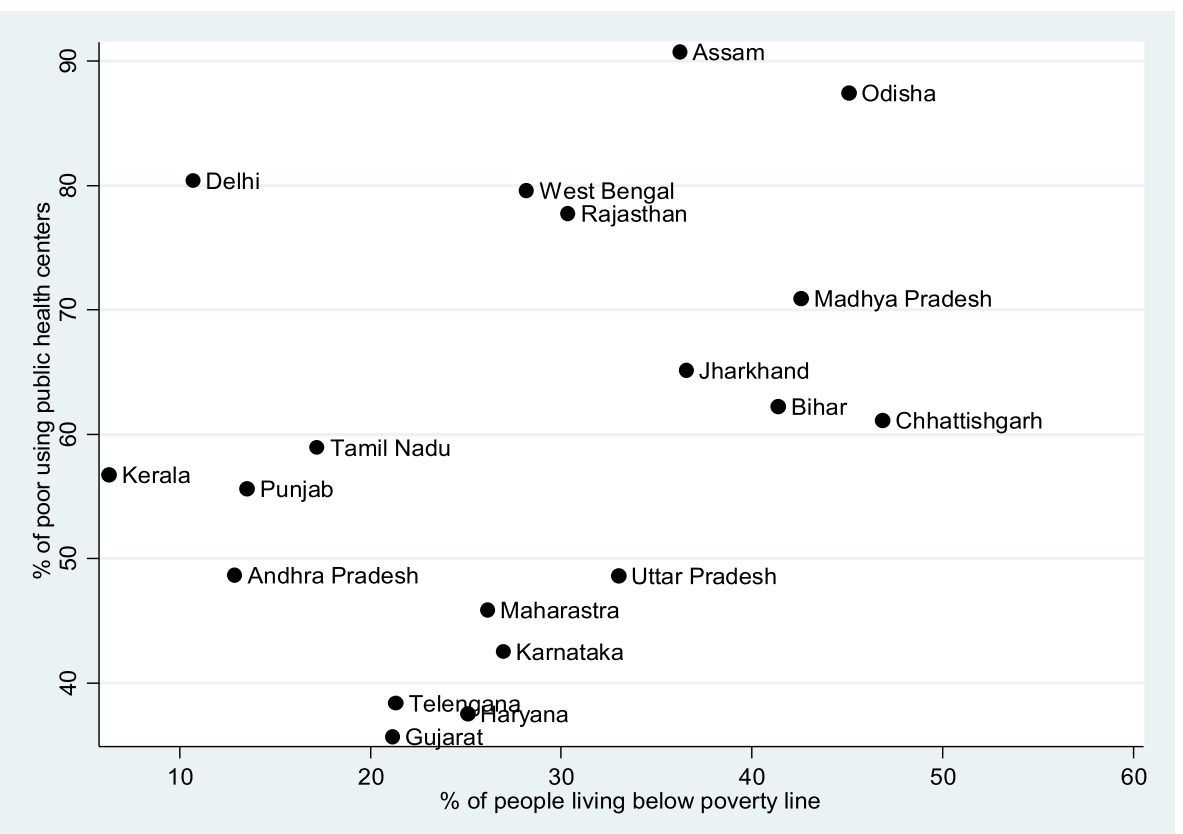

Fig. 2 Percentage of population living below poverty line and hospitalization in public health centers in major states of India (pdf $437 \mathrm{~kb}$ ) 
Table 2 Hospitalization (\%) among the poor and non-poor in public and private health centers of India, 2014

\begin{tabular}{|c|c|c|c|c|c|c|c|}
\hline \multirow[t]{2}{*}{ States } & \multirow{2}{*}{$\begin{array}{l}\% \text { of poor } \\
\text { hospitalized } \\
\text { in public } \\
\text { health } \\
\text { centers }\end{array}$} & \multirow{2}{*}{$\begin{array}{l}\% \text { of non- } \\
\text { poor } \\
\text { hospitalized } \\
\text { in public } \\
\text { health } \\
\text { centers }\end{array}$} & \multirow{2}{*}{$\begin{array}{l}\mathrm{T} \\
\text { statistic }\end{array}$} & \multirow{2}{*}{$\begin{array}{l}\% \text { of } \\
\text { people } \\
\text { living } \\
\text { below } \\
\text { poverty } \\
\text { line }\end{array}$} & \multicolumn{3}{|c|}{ Number of episode of hospitalization } \\
\hline & & & & & Poor & Non-poor & All \\
\hline Tamil Nadu & 58.90 & 34.70 & 11.15 & 17.22 & 671 & 3118 & 3789 \\
\hline Jharkhand & 65.13 & 48.03 & 6.21 & 36.57 & 432 & 758 & 1190 \\
\hline Telengana & 38.35 & 23.92 & 6.81 & 21.34 & 257 & 1018 & 1275 \\
\hline Andhra Pradesh & 48.66 & 22.45 & 10.05 & 12.91 & 368 & 2021 & 2389 \\
\hline Rajasthan & 77.76 & 57.42 & 8.88 & 30.37 & 742 & 1888 & 2630 \\
\hline Kerala & 56.76 & 32.31 & 9.17 & 6.31 & 257 & 2745 & 3002 \\
\hline Chhattisgarh & 61.12 & 46.53 & 5.79 & 46.87 & 408 & 492 & 900 \\
\hline Karnataka & 42.53 & 28.38 & 7.30 & 26.97 & 773 & 2059 & 2832 \\
\hline Maharashtra & 45.89 & 18.77 & 17.35 & 26.16 & 1471 & 3538 & 5009 \\
\hline Madhya Pradesh & 70.90 & 54.90 & 11.62 & 42.59 & 1292 & 1820 & 3112 \\
\hline Bihar & 62.24 & 50.56 & 4.41 & 41.40 & 1016 & 1359 & 2375 \\
\hline Gujarat & 35.71 & 23.67 & 5.99 & 21.17 & 594 & 2105 & 2699 \\
\hline Assam & 90.71 & 85.50 & 5.23 & 36.24 & 619 & 1091 & 1710 \\
\hline Odisha & 87.43 & 74.12 & 10.01 & 45.09 & 953 & 1159 & 2112 \\
\hline West Bengal & 79.57 & 66.82 & 12.70 & 28.19 & 1318 & 3173 & 4491 \\
\hline Uttar Pradesh & 48.60 & 36.79 & 7.84 & 33.02 & 2195 & 4244 & 6439 \\
\hline Haryana & 37.51 & 32.21 & 3.84 & 25.10 & 331 & 942 & 1273 \\
\hline Delhi & 83.10 & 46.27 & 5.52 & 10.70 & 85 & 785 & 870 \\
\hline Punjab & 55.64 & 31.19 & 5.44 & 13.54 & 182 & 1146 & 1328 \\
\hline India & 60.71 & 39.80 & 42.20 & 26.80 & 27439 & 30017 & 57456 \\
\hline
\end{tabular}

centers, $11 \%$ were poor households and used private health centers, $29 \%$ were non-poor households using public health centers and $44 \%$ were non-poor households using private health centers. The state pattern is striking; a higher proportion of the poor were using public health centers in the poorer states of Odisha (39\%), Assam (33\%), Madhya Pradesh (30\%), Chhattisgarh (29\%) and Bihar (26\%). In many of the poorer states, a significantly higher proportion of population was using public health centers. It also suggests that a higher proportion of the non-poor in the economically better-off states utilized private health centers.

Inter-state variations in OOPE on hospitalization in public and private health centers by level of poverty

Table 3 presents the OOPE among the poor and the non-poor by type of health care centers in the states of India. In 2014, the mean OOPE per episode of hospitalization in public health centers was ₹5688 compared to ₹24924 in private health centers. The OOPE per episode of hospitalization in public health centers was lowest in Tamil Nadu (₹2395) and highest in Punjab (₹10540). On the other hand, the OOPE per episode of hospitalization among the poor in public health centers of the empowered action group states (EAGs), namely, Bihar, Jharkhand, Odisha, Madhya Pradesh, Chhattisgarh, Assam, and Uttar Pradesh was higher than that in Tamil Nadu. The OOPE per episode of hospitalization of the poor using private health centers was consistently lower than that of the non-poor using private health centers across the states of India. Among the states the non-poor using private health centers, the OOPE was highest in Delhi (₹44208) and lowest in Jharkhand (₹15835). The OOPE was higher in private health centers than in public health centers in each state of India. The coefficient of variation of OOPE in public health centers was 35 and that in private health centers was 28 . In most of the states, the OOPE accounts for more than $95 \%$ of total health expenditure of hospitalization care.

Appendix 2 of Additional file 2 presents the mean OOPE per episode of hospitalization by type of disease and health centers in the states of India. The mean OOPE per episode of hospitalization for NCDs in public health centers was ₹7485 compared to ₹24927 in private health centers of India. Among the four broad diseases categories, the OOPE per episode of hospitalization for 


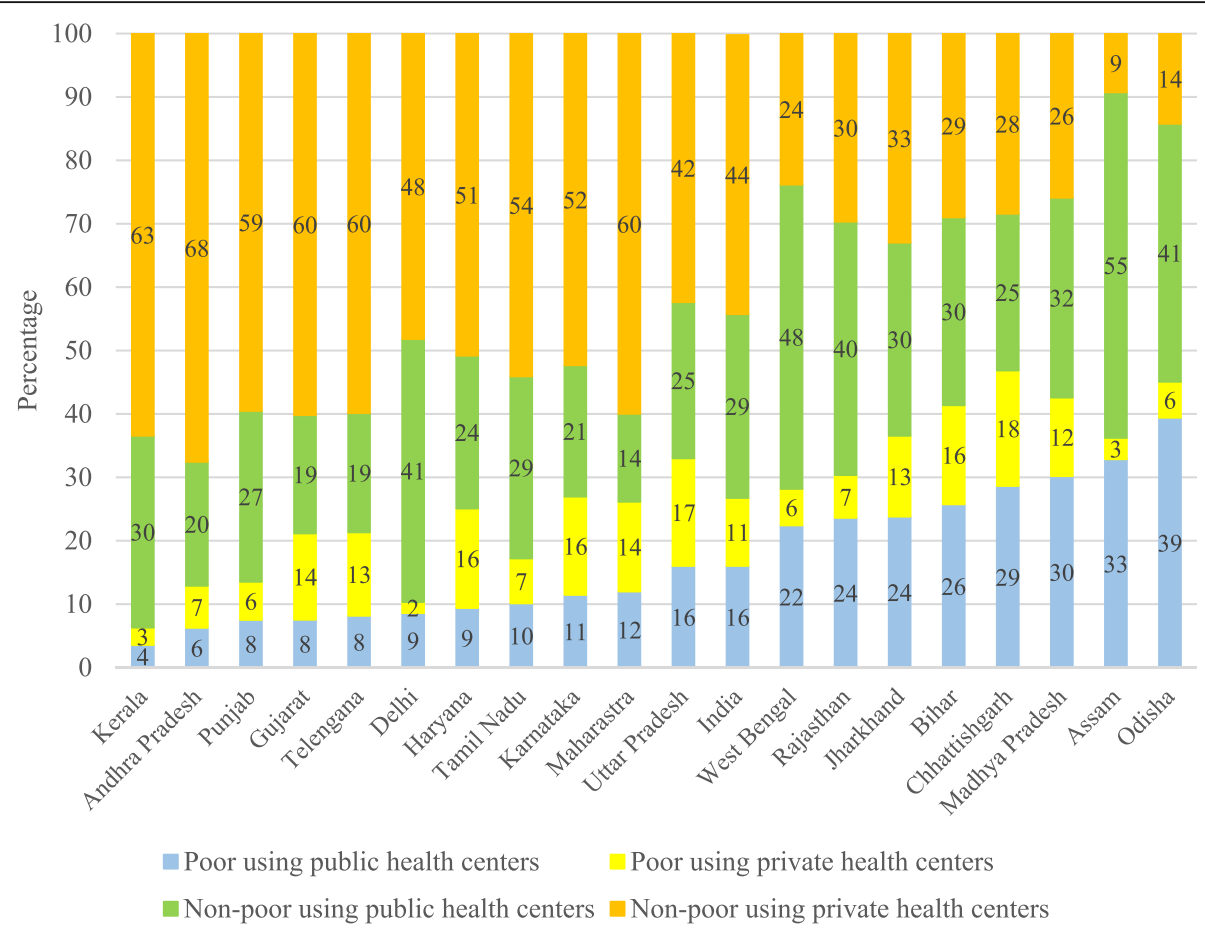

Fig. 3 Percentage distribution of poor and non-poor hospitalized in public and private health centers in states of India, 2014

Table 3 Out-of-pocket expenditure (₹) per episode of hospitalization by poverty and type of health centers in the states of India, 2014

\begin{tabular}{|c|c|c|c|c|c|c|c|c|c|}
\hline States & $\begin{array}{l}\text { Poor using public } \\
\text { health centers }\end{array}$ & $\begin{array}{l}\text { Poor using private } \\
\text { health centers }\end{array}$ & $\begin{array}{l}\text { Non-poor using } \\
\text { public health centers }\end{array}$ & $\begin{array}{l}\text { Non-poor using } \\
\text { private health centers }\end{array}$ & All & $\begin{array}{l}\text { F- } \\
\text { statistics }\end{array}$ & $\begin{array}{l}\text { Public } \\
\text { health } \\
\text { centers }\end{array}$ & $\begin{array}{l}\text { Private } \\
\text { health } \\
\text { centers }\end{array}$ & $\begin{array}{l}\text { OOPE as a share } \\
\text { of Total cost }\end{array}$ \\
\hline Tamil Nadu & 1900 & 17485 & 2569 & 29444 & 18084 & 145.80 & 2395 & 28059 & 93.87 \\
\hline Jharkhand & 2534 & 15638 & 4972 & 15835 & 9333 & 21.03 & 3903 & 15780 & 98.83 \\
\hline Telangana & 2696 & 19328 & 4715 & 28136 & 20488 & 12.20 & 4103 & 26549 & 98.20 \\
\hline $\begin{array}{l}\text { Andhra } \\
\text { Pradesh }\end{array}$ & 2477 & 11353 & 4881 & 24841 & 18640 & 25.60 & 4296 & 23636 & 98.63 \\
\hline Rajasthan & 2790 & 11946 & 5191 & 26875 & 11510 & 119.21 & 4299 & 24105 & 96.41 \\
\hline Kerala & 3863 & 19222 & 4392 & 24559 & 17568 & 45.94 & 4336 & 24339 & 96.02 \\
\hline Chhattisgarh & 2881 & 18072 & 6371 & 27186 & 13416 & 27.59 & 4498 & 23625 & 98.06 \\
\hline Karnataka & 4080 & 16231 & 4887 & 22114 & 15563 & 62.16 & 4600 & 20769 & 91.39 \\
\hline Maharashtra & 3701 & 22381 & 5398 & 27071 & 20598 & 72.09 & 4610 & 26176 & 91.60 \\
\hline $\begin{array}{l}\text { Madhya } \\
\text { Pradesh }\end{array}$ & 3190 & 21372 & 6614 & 26675 & 12604 & 91.50 & 4939 & 24959 & 91.29 \\
\hline Bihar & 4128 & 17359 & 6631 & 20730 & 11748 & 62.79 & 5467 & 19549 & 98.56 \\
\hline Gujarat & 2347 & 11935 & 7037 & 18461 & 14223 & 31.92 & 5684 & 17257 & 92.83 \\
\hline Assam & 5557 & 13953 & 6907 & 54097 & 11064 & 60.52 & 6399 & 43381 & 96.96 \\
\hline Odisha & 5882 & 25973 & 7481 & 35055 & 11818 & 105.61 & 6694 & 32466 & 97.81 \\
\hline West Bengal & 7930 & 23462 & 6840 & 31778 & 13983 & 107.64 & 7187 & 30159 & 92.40 \\
\hline $\begin{array}{l}\text { Uttar } \\
\text { Pradesh }\end{array}$ & 3085 & 17143 & 9981 & 29412 & 18317 & 109.26 & 7262 & 25902 & 99.02 \\
\hline Haryana & 6840 & 28127 & 8931 & 24870 & 19838 & 22.84 & 8344 & 25639 & 89.62 \\
\hline Delhi & 4218 & 66844 & 9644 & 44208 & 26829 & 19.17 & 8713 & 45000 & 85.27 \\
\hline Punjab & 8715 & 22989 & 11050 & 33974 & 25229 & 8.44 & 10540 & 32966 & 96.49 \\
\hline India & 4264 & 18454 & 6482 & 26470 & 16189 & 1106.11 & 5688 & 24924 & 94.82 \\
\hline
\end{tabular}


accident and others was highest in both public and private health centers. The state pattern was similar but there were large variations among the states. In Tamil Nadu, the mean OOPE per episode of hospitalization for treating NCDs in public health centers was ₹2187 compared to ₹26008 in private health centers. It was highest in the poorer states of Uttar Pradesh (₹16406), followed by Bihar (₹ 10796). The mean OOPE per episode of hospitalization in private health centers for NCDs was highest in Delhi (₹47187) and lowest in Jharkhand (₹16364). In case of CDs hospitalized in public health centers, it was highest in Assam (₹5101) followed by Odisha (₹4800) and lowest in Gujarat (₹1427).

Table 4 presents the ratio of OOPE on hospitalization by type of health center and extent of poverty in states of India. The OOPE of Tamil Nadu has been taken as the reference category. The OOPE for hospitalization in public health centers of India was 2.38 times higher than that in Tamil Nadu (column 7, Table 4). The OOPE in public health centers in the poorer states of Bihar, Odisha, and Uttar Pradesh was higher than that in Tamil Nadu by 2.3, 2.8 and 3.0 times respectively. The OOPE of the poor using public health centers in the poorer states of Odisha was 3.10 times higher than those in Tamil Nadu. Inter-state variations were not large in the private health centers of India. The ratio of non-poor using private health centers was lower in Jharkhand (0.54) than in Tamil Nadu.

\section{Inter-state variations on direct and indirect costs of hospitalization}

Appendix 3 of Additional file 3 presents the state pattern of health spending segregated for direct medical cost (cost of medicines, tests, doctor's fee, and bed charges) and indirect medical cost (transportation and others). The share of direct cost in public health centers in India was $76 \%$ and that of indirect cost was $24 \%$. The state pattern is distinct. Among those using public health centers, the share of direct cost was the lowest in Tamil Nadu (23\%) and highest in Uttar Pradesh and Punjab (87\% each). Among poor using public health centers, the direct cost of hospitalization was also lowest in Tamil Nadu (14\%) and the highest in Punjab (87\%), followed by West Bengal (86\%). The share of direct cost on hospitalization in public health centers among the

Table 4 Ratio of out-of-pocket expenditure on hospitalization among major states of India with respect to Tamil Nadu, 2014

\begin{tabular}{|c|c|c|c|c|c|c|c|}
\hline States & $\begin{array}{l}\text { Poor using public } \\
\text { health centers }\end{array}$ & $\begin{array}{l}\text { Poor using private } \\
\text { health centers }\end{array}$ & $\begin{array}{l}\text { Non-poor using public } \\
\text { health centers }\end{array}$ & $\begin{array}{l}\text { Non-poor using private } \\
\text { health centers }\end{array}$ & All & $\begin{array}{l}\text { Public health } \\
\text { centers }\end{array}$ & $\begin{array}{l}\text { Private health } \\
\text { centers }\end{array}$ \\
\hline Tamil Nadu & 1.00 & 1.00 & 1.00 & 1.00 & 1.00 & 1.00 & 1.00 \\
\hline Jharkhand & $1.33^{* * *}$ & 0.89 & 1.94 & $0.54^{* * *}$ & $0.52^{* * *}$ & $1.63^{* * *}$ & $0.56^{* * *}$ \\
\hline Telangana & $1.42^{* * *}$ & 1.11 & $1.84^{* * *}$ & 0.96 & $1.13^{* * *}$ & $1.71^{* * *}$ & 0.95 \\
\hline $\begin{array}{l}\text { Andhra } \\
\text { Pradesh }\end{array}$ & 1.30 & $0.65^{* * *}$ & $1.90^{* * *}$ & 0.84 & 1.03 & $1.79^{* * *}$ & $0.84^{* * *}$ \\
\hline Rajasthan & $1.47^{* * *}$ & $0.68^{* *}$ & $2.02^{* * *}$ & 0.91 & $0.64^{* * *}$ & $1.80^{* * *}$ & $0.86^{* *}$ \\
\hline Kerala & $2.03^{* * *}$ & 1.10 & $1.71^{* * *}$ & $0.83^{* * *}$ & 0.97 & $1.81^{* * *}$ & $0.87^{* * *}$ \\
\hline Chhattisgarh & $1.52^{* *}$ & 1.03 & $2.48^{* * *}$ & 0.92 & 0.74 & $1.88^{* * *}$ & 0.84 \\
\hline Karnataka & $2.15^{* * *}$ & 0.93 & $1.90^{* * *}$ & $0.75^{* * *}$ & 0.86 & $1.92^{* * *}$ & $0.74^{* * *}$ \\
\hline Maharashtra & $1.95^{* * *}$ & 1.28 & $2.10^{* * *}$ & 0.92 & $1.14^{* *}$ & $1.93^{* * *}$ & 0.93 \\
\hline $\begin{array}{l}\text { Madhya } \\
\text { Pradesh }\end{array}$ & $1.68^{* * *}$ & 1.22 & $2.57^{* * *}$ & 0.91 & $0.70^{* *}$ & $2.06^{* * *}$ & 0.89 \\
\hline Bihar & $2.17^{* * *}$ & 0.99 & $2.58^{* * *}$ & 0.70 & 0.65 & $2.28^{* * *}$ & $0.70^{* *}$ \\
\hline Gujarat & $1.23^{* *}$ & $0.68^{* * *}$ & $2.74^{* * *}$ & $0.63^{* * *}$ & $0.79^{* * *}$ & $2.37^{* * *}$ & $0.62^{* * *}$ \\
\hline Assam & $2.92^{* * *}$ & 0.80 & $2.69^{* * *}$ & $1.84^{* *}$ & $0.61^{* *}$ & $2.67^{* * *}$ & $1.55^{* *}$ \\
\hline Odisha & $3.10^{* * *}$ & 1.49 & $2.91^{* * *}$ & $1.19^{*}$ & $0.65^{* * *}$ & $2.80^{* * *}$ & $1.16^{*}$ \\
\hline West Bengal & $4.17^{* * *}$ & 1.34 & $2.66^{* * *}$ & 1.08 & $0.77^{* *}$ & $3.00^{* * *}$ & 1.07 \\
\hline $\begin{array}{l}\text { Uttar } \\
\text { Pradesh }\end{array}$ & $1.62^{* * *}$ & 0.98 & $3.89^{* * *}$ & 1.00 & $1.01^{*}$ & $3.03^{* * *}$ & 0.92 \\
\hline Haryana & $3.60^{* * *}$ & 1.61 & $3.48^{* * *}$ & 0.84 & $1.10^{*}$ & $3.48^{* * *}$ & 0.91 \\
\hline Delhi & $2.22^{* *}$ & $3.82^{* *}$ & $3.75^{* * *}$ & $1.50^{*}$ & $1.48^{* * *}$ & $3.64^{* * *}$ & $1.60^{* * *}$ \\
\hline Punjab & $4.59^{* *}$ & $1.31^{*}$ & $4.30^{* * *}$ & 1.15 & $1.40^{* * *}$ & $4.40^{* * *}$ & 1.17 \\
\hline India & 2.24 & 1.06 & 2.52 & 0.90 & 0.90 & 2.38 & 0.89 \\
\hline
\end{tabular}

Note: States are arranged in ascending order of OOPE in public health centers. t-test shows significant differences in OOPE of Tamil Nadu with each of the state in respective category $\left({ }^{* *} p<0.001,{ }^{* *} p<0.01,{ }^{*} p<0.05\right)$ 
poor in poorer states such as Bihar, Odisha, and Uttar Pradesh was over $70 \%$ of the total cost.

Table 5 presents the percentage distribution of medical expenditure on hospitalization by doctor's fees, cost of medicines, cost of diagnostic tests, bed charges, other medical expenditure, transportation and other non-medical expenditure in public and private health centers, and poverty in a developed state, Tamil Nadu and a poorer state, Bihar. We have also presented the estimates of India. Among the poor using public health centers in India, the share of medicine to total health cost was $38,13 \%$ on diagnostic tests, $7 \%$ on doctor's fees, and $3 \%$ on bed charges. In the case of Bihar, the share of medicine on total cost of hospitalization was largest (45\%) while it was least in Tamil Nadu (4\%). The pattern was similar among the non-poor who were using public health centers. In public health centers of Tamil Nadu, the share of doctor's fees, medicines, diagnostic tests, bed charges, and all other medical expenses accounted $0.47,7.64,7.72,0.35$ and $6.78 \%$ respectively. The expenditure on medicines accounted for the largest share of CHPE in all the states except Tamil Nadu. In public health centers in Bihar, the share of doctor's fees, medicines, diagnostic tests, bed charges and all other medical expenses accounted for $12,38,9,3$ and $8 \%$ of the CHPE respectively. Similar state-wise variations were noticed in each of the component across the states of India.
Figure 4 presents the percentage share of direct and indirect cost, irrespective of poverty and type of health centers for Tamil Nadu and Bihar. In Tamil Nadu, the share of doctor's fees, medicines, diagnostic tests, bed charges, and all other medical expenses was $27,24,11,13,9,4$, and $11 \%$, while it was $33,18,10$, $10,7,7$, and $14 \%$ in Bihar. In general, differences on CHPE between richer and poorer state is large due to public health centers.

\section{Supply of healthcare services in public health centers in states of India}

Table 6 presents the supply side factors that may have an impact on variations in CHPE across the states of India. In India, the shortfall of PHC from required norms was $17 \%$ and it was $29 \%$ for $\mathrm{CHC}$. The shortfall of PHC was highest in Jharkhand (66\%) while there was no shortfall of PHCs in Kerala, Chhattisgarh, Karnataka, and Assam. The shortfall of $\mathrm{CHC}$ was high in Bihar (91\%), while there was no shortfall of $\mathrm{CHC}$ in Tamil Nadu and Kerala. Availability of bed per one lakh population is one of the most important supply side factors in any developing country. In India, the total number of beds per one lakh population was 114 in public hospitals and ranged from 137 in Delhi to 13 in Bihar. According to Indian public health standard (IPHS) norms, each PHC must have a qualified medical officer with at-least three nurses and six beds. The availability of human resources such as medical and paramedical staffs

Table 5 Share (\%) of direct and indirect cost by poverty and type of health centers in India, Tamil Nadu, and Bihar, 2014

\begin{tabular}{|c|c|c|c|c|c|c|c|}
\hline \multirow[b]{2}{*}{ Poverty } & \multicolumn{5}{|c|}{ Direct cost } & \multicolumn{2}{|c|}{ Indirect cost } \\
\hline & Doctor & Medicine & Diagnostic & Bed & Other medical & Transport & Other non-medical \\
\hline \multicolumn{8}{|l|}{ India } \\
\hline Poor using public health centers & 6.69 & 37.75 & 13.59 & 2.75 & 9.62 & 10.52 & 19.08 \\
\hline Poor using private health centers & 23.13 & 30.25 & 10.78 & 13.86 & 9.33 & 4.25 & 8.41 \\
\hline Non-poor using public health centers & 7.97 & 33.60 & 12.31 & 3.12 & 14.81 & 9.29 & 18.91 \\
\hline Non-poor using private health centers & 25.32 & 27.69 & 11.66 & 14.71 & 9.13 & 3.66 & 7.83 \\
\hline Utilization of public health centers (All) & 7.60 & 34.79 & 12.68 & 3.01 & 13.31 & 9.65 & 18.96 \\
\hline \multicolumn{8}{|l|}{ Tamil Nadu } \\
\hline Poor using public health centers & 0.60 & 3.72 & 4.58 & 0.00 & 5.51 & 21.99 & 63.60 \\
\hline Poor using private health centers & 32.63 & 22.80 & 10.00 & 14.88 & 7.36 & 3.93 & 8.41 \\
\hline Non-poor using public health centers & 0.44 & 8.67 & 8.55 & 0.44 & 7.12 & 15.79 & 59.00 \\
\hline Non-poor using private health centers & 28.65 & 25.73 & 11.34 & 13.55 & 9.13 & 3.64 & 7.96 \\
\hline Utilization of public health centers (All) & 0.47 & 7.64 & 7.72 & 0.35 & 6.78 & 17.08 & 59.95 \\
\hline \multicolumn{8}{|l|}{ Bihar } \\
\hline Poor using public health centers & 6.69 & 45.48 & 9.99 & 3.17 & 7.82 & 9.98 & 16.86 \\
\hline Poor using private health centers & 19.05 & 38.34 & 9.20 & 13.30 & 5.19 & 4.58 & 10.34 \\
\hline Non-poor using public health centers & 15.29 & 33.29 & 9.20 & 3.33 & 9.35 & 10.64 & 18.91 \\
\hline Non-poor using private health centers & 21.11 & 27.91 & 10.45 & 12.64 & 8.05 & 5.78 & 14.06 \\
\hline Utilization of public health centers (All) & 12.07 & 37.85 & 9.50 & 3.27 & 8.87 & 10.39 & 18.15 \\
\hline
\end{tabular}




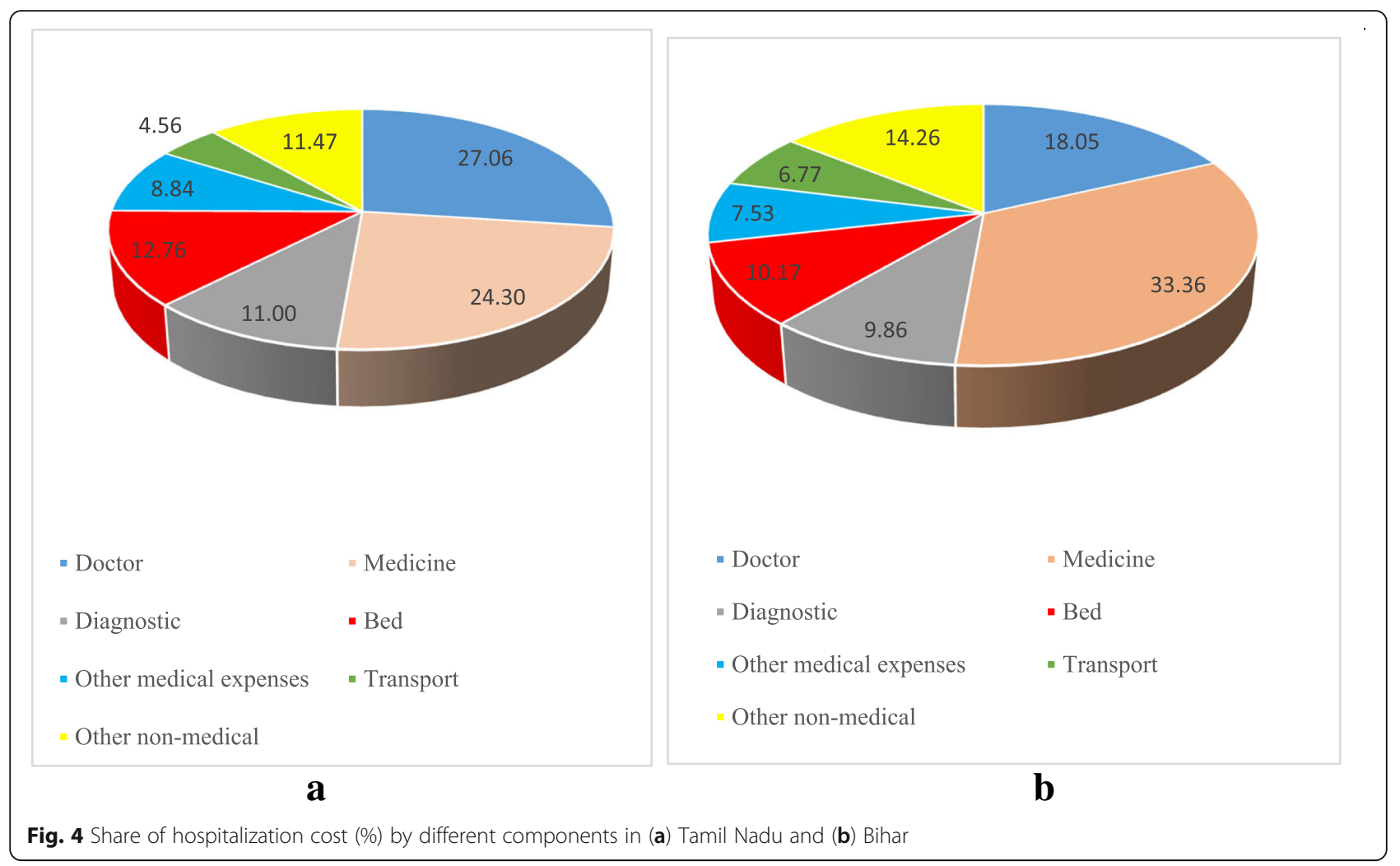

and infrastructure (availability of bed at PHC) was not satisfactory in many of the poorer states of India.

Figure 5 presents the spatial distribution of districts with shortfall of human resources (doctors and nurses) and infrastructure (bed) in the PHC of India. Figure 5 (a) shows that shortfall of doctor in PHC in 131 districts of India was high (25\% and above). The shortfall of nurses was high (65\% and above) in the PHC of 256 districts in India (Fig. 5 b). Noticeably, all the districts of Odisha and Uttar Pradesh had shortfall of beds in PHC (Fig. 5 c). The average distance from the village to the nearest PHC was above $15 \mathrm{~km}(\mathrm{KM})$ in 45 districts, especially in the remote hilly areas of India (Fig. 5 d).

\section{Determinants of the cost of hospitalization}

Table 7 presents the result of log-linear regression model that used CHPE as the dependent variable controlling for various socio economic and demographic factors. The model is estimated for India and two disparate states, namely, Bihar and Tamil Nadu. In India, all the socio-economic and demographic factors except place of residence adjusted in the model are significant. The composite variable of poverty and type of health centers are significant predictors in the model. The CHPE of poor using public health centers in India was 51\% $((\exp (0.71)-1))$ lower than that of the non-poor using private health centers. Similarly, the CHPE of poor using private health centers was $18 \%((\exp (0.20)-1))$ lower than that of the non-poor using private health centers. The CHPE of non-poor using public health centers was $43 \%$ $((\exp (0.56)-1))$ lower than that of the non-poor using private health centers.

Among other variables, those who were hospitalized and underwent surgery, the CHPE had higher by $133 \%$ $((\exp (0.85)-1))$ than those hospitalized without surgery (Table 7). The results also revealed that those individuals were insured for health, spent $67 \%((\exp (0.51)-1))$ higher CHPE compared to those who were not insured. Similarly, those individuals treated for any others NCDs had lower CHPE compared to those treated for cancer. The significant predictors in both Bihar and Tamil Nadu are poverty and type of hospital, surgery, medicine and diagnostic services, health insurance benefit and diseases. The general pattern in variable of interest (poverty and type of health centers) is similar in Bihar and Tamil Nadu but the coefficient varies.

\section{Robustness analysis}

As a robustness check, we perform a tobit regression model using CHPE as depended variable. Appendix 4 of Additional file 4 presents the marginal effect along with 95\% confidence interval of CHPE estimated for India, Bihar and Tamil Nadu. The CHPE of the individuals belonging to poor households and using public health centers for hospitalization in India was ₹4835 $(p<0.001$, CI $-5585,-4085)$ lower than that of the non-poor who were using private health centers. Similarly, the CHPE of 
Table 6 Shortfall in public health facilities (\%), primary health center, number of beds per one lakh population and health worker per 1000 population in States of India, 2013

\begin{tabular}{|c|c|c|c|c|c|c|c|c|c|}
\hline \multirow[t]{2}{*}{ States } & \multicolumn{3}{|c|}{ Shortfall in public health facilities } & \multirow{2}{*}{$\begin{array}{l}\text { Bed per } \\
\text { one lakh } \\
\text { population }\end{array}$} & \multicolumn{3}{|c|}{ Shortfall in primary health center } & \multirow{2}{*}{$\begin{array}{l}\text { Distance } \\
\text { between } \\
\text { village to } \\
\text { PHC }\end{array}$} & \multirow{2}{*}{$\begin{array}{l}\text { Health } \\
\text { worker per } \\
1000 \\
\text { population } \\
\text { in } 2011\end{array}$} \\
\hline & SC & $\mathrm{PHC}$ & $\mathrm{CHC}$ & & No doctor & Less than 3 Nurse & less than 6 bed & & \\
\hline Tamil Nadu & 0.0 & 1.8 & 0.0 & 86 & 2.2 & 31.6 & 61.5 & 7.9 & 4.3 \\
\hline Jharkhand & 34.7 & 65.8 & 22.0 & 16 & 27.3 & 63.6 & 30.9 & 4.3 & 2.4 \\
\hline Telengana & 15.4 & 16.7 & 29.2 & NA & 2.5 & 14.7 & 28.9 & 9.9 & 4.2 \\
\hline Andhra Pradesh & 0.0 & 13.0 & 40.5 & 77 & 2.2 & 10.5 & 41.8 & 9.0 & 3.8 \\
\hline Rajasthan & 0.0 & 13.5 & 7.3 & 56 & 14.8 & 43.9 & 23.4 & 11.0 & 3.0 \\
\hline Kerala & 0.0 & 0.0 & 0.0 & 111 & 5.5 & 23.2 & 58.0 & 4.8 & 8.5 \\
\hline Chhattisgarh & 0.0 & 0.0 & 18.7 & 42 & 52.2 & 96.3 & 13.2 & 8.8 & 2.3 \\
\hline Karnataka & 0.0 & 0.0 & 42.3 & 85 & 10.6 & 22.1 & 8.3 & 7.0 & 4.3 \\
\hline Maharashtra & 21.7 & 17.7 & 34.4 & 42 & 0.6 & 79.3 & 3.6 & 10.1 & 5.3 \\
\hline Madhya Pradesh & 28.6 & 41.9 & 33.0 & 42 & 40.9 & 78.4 & 31.0 & 10.7 & 3.2 \\
\hline Bihar & 47.8 & 39.2 & 91.0 & 13 & 5.6 & 51.8 & 14.9 & 8.3 & 1.8 \\
\hline Gujarat & 9.2 & 10.2 & 1.2 & 59 & NA & NA & NA & NA & 4.1 \\
\hline Assam & 21.2 & 0.0 & 53.8 & 33 & 6.1 & 59.4 & 70.1 & 6.4 & 4.2 \\
\hline Odisha & 18.4 & 0.8 & 0.0 & 40 & 32.7 & 96.5 & 91.5 & 6.3 & 4.2 \\
\hline West Bengal & 20.8 & 57.8 & 35.5 & 85 & 11.8 & 58.3 & 58.3 & 4.5 & 4.4 \\
\hline Uttar Pradesh & 34.2 & 32.7 & 40.4 & 79 & 25.4 & 94.9 & 88.5 & 5.4 & 2.3 \\
\hline Haryana & 23.5 & 17.8 & 19.7 & 31 & 13.8 & 28.9 & 48.8 & 6.9 & 3.8 \\
\hline Delhi & 54.2 & 61.5 & NA & 137 & NA & NA & NA & NA & 7.8 \\
\hline Punjab & 14.9 & 24.6 & 1.4 & 41 & 13.6 & 35.8 & 63.0 & 4.9 & 4.7 \\
\hline India & 15.4 & 16.7 & 29.2 & 114 & 15.9 & 58.1 & 41.5 & 8.4 & 3.8 \\
\hline
\end{tabular}

individuals belonging to poor households and using private health centers was ₹4585 ( $p<0.001$, CI -5314, $3856)$, while the non-poor using public health centers spent ₹4921 ( $\mathrm{p}<0.001$, CI -5782, - 4059) less than the non-poor using private health centers. The CHPE of individuals belonging to the poor households and using public health centers in Bihar was ₹4478 $(p<0.001, \mathrm{CI}$ -8352, -605), while poor households using private health centers spent ₹5983 ( $p<0.001$, CI -9334, - 2633), and non-poor households and using public health centers spent $₹ 3788$ ( $\mathrm{p}<0.001$, CI -8292, 716) less than the non-poor and using private health centers. Similarly, in Tamil Nadu CHPE of individuals belonging to poor households and using public health centers was ₹5482 $(p<0.001$, CI $-9302,-1662)$, while that of poor households using private health centers was ₹5172 ( $\mathrm{p}<0.001$, CI -7664, - 2681), individuals belonging to non-poor households using public health centers spent ₹5821 ( $p<$ 0.01$, CI $-9694,-1990)$ less than the non-poor using private health centers. Our results of Tobit model supports the findings of the log-linear regression model.

\section{Discussion}

The health spending in developing countries, unlike that in developed countries, is largely met by the households.
Studies across developing countries suggests that poor households often resort to borrowing or selling assets to meet the OOPE for hospitalization [33, 40, 41, 57]. Many developing countries have introduced varying financial protection schemes and strengthened the public health centers to protect the poor and needy from high OOPE and rising health care costs. However, disparities in access and inequality in health outcome persists across and within countries. In India, rising health care cost is affecting the poor and vulnerable the most. Recent studies suggests that the state variations in CHS are large and the CHS has increased among the poor and marginalized [9, 27]. The public health centers in India are intended to provide free/affordable health services to the poor. But, the cost, and quality of services in public health centers vary largely across and within the states. Using the health survey data on hospitalization care, this study examined the inter-state variations of OOPE on hospitalization by level of poverty and type of health centers in India. The followings are the salient findings of the paper.

First, utilization of public health centers is higher among the poor than among the non-poor cutting across the states. More than half of the poor people in the poorer states of Assam, Odisha, Madhya Pradesh, 

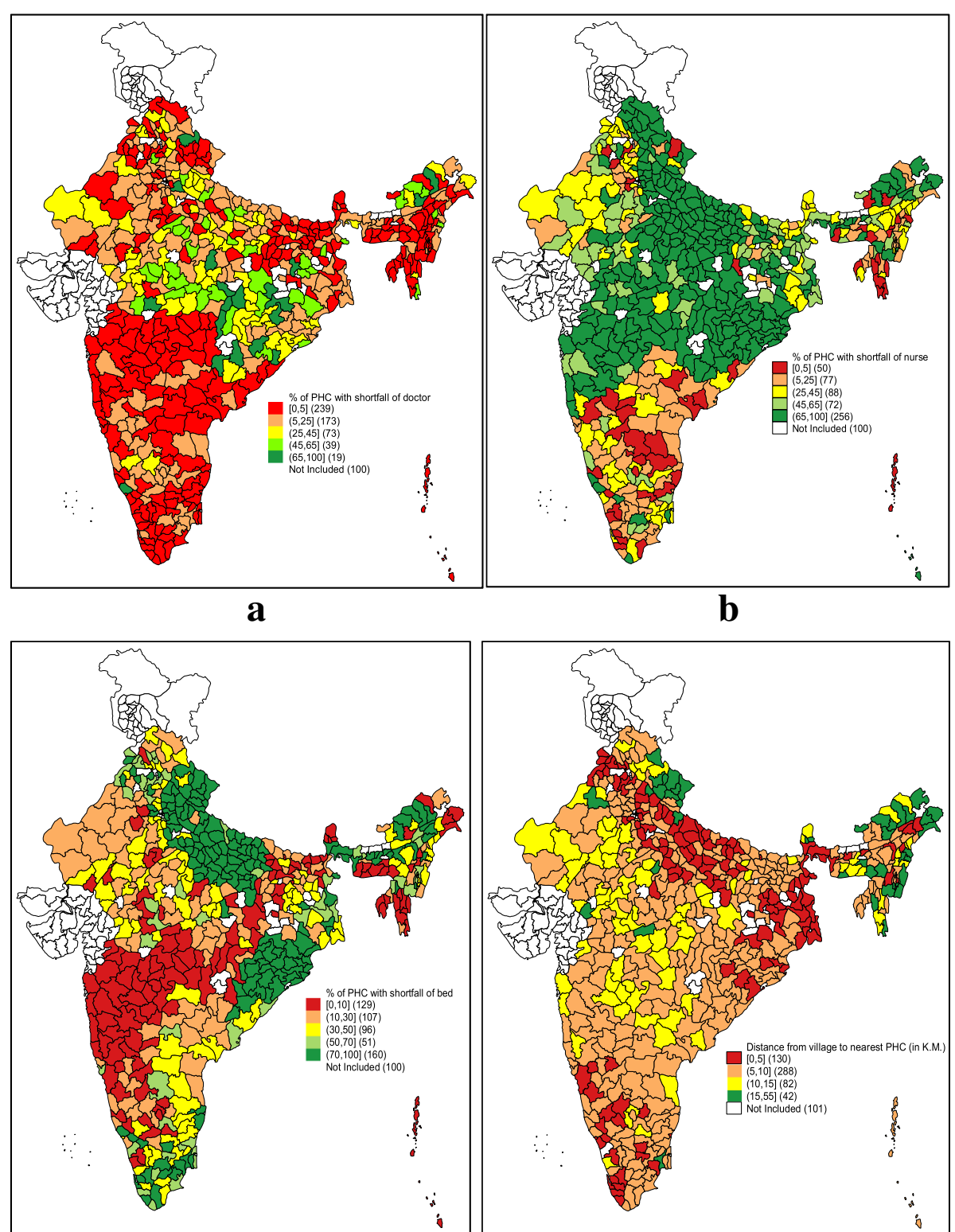

c

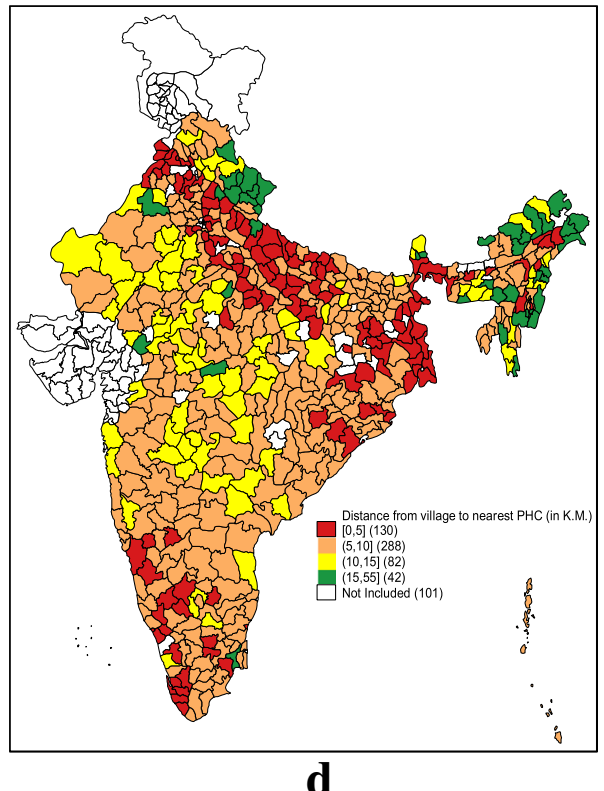

Fig. 5 Geographical distribution of primary health center (PHC) (\%) with shortfall of (a) doctor (b) shortfall of nurse (c) shortfall of bed (d) distance from village to PHC (in kilometer) in districts of India in 2013

Bihar, Jharkhand, and Chhattisgarh was hospitalized in public health centers, significantly higher than those in the developed states of Kerala and Andhra Pradesh. The findings suggest that poor people continued to rely on public health centers for utilization of inpatient services in India. Second, the OOPE accounts for over $95 \%$ of the cost of hospitalization of India. It varies from $85 \%$ in Delhi to $99 \%$ in the poorer states of Uttar Pradesh, Bihar and Jharkhand suggesting that most of the spending on hospitalization is largely met by the households in India. Third, the state pattern of OOPE in the public and private health centers is striking. The mean OOPE per episode of hospitalization in public health centers of Tamil Nadu was lowest among all states of India, while it was twice that of Tamil Nadu in the poorer states of Odisha, Assam and Bihar. We also found significant differences on OOPE in public health centers across the states of India. Though the CHPE was lowest in the public health centers of Tamil Nadu, it was not the case in private health centers. Many of the states had lower OOPE in private health centers than those in Tamil Nadu. The OOPE in private health centers was four times higher than that in public health centers in India. The state pattern suggests that CHPE in private health 
Table 7 Result of log-linear regression model on cost of hospitalization in India, Bihar and Tamil Nadu

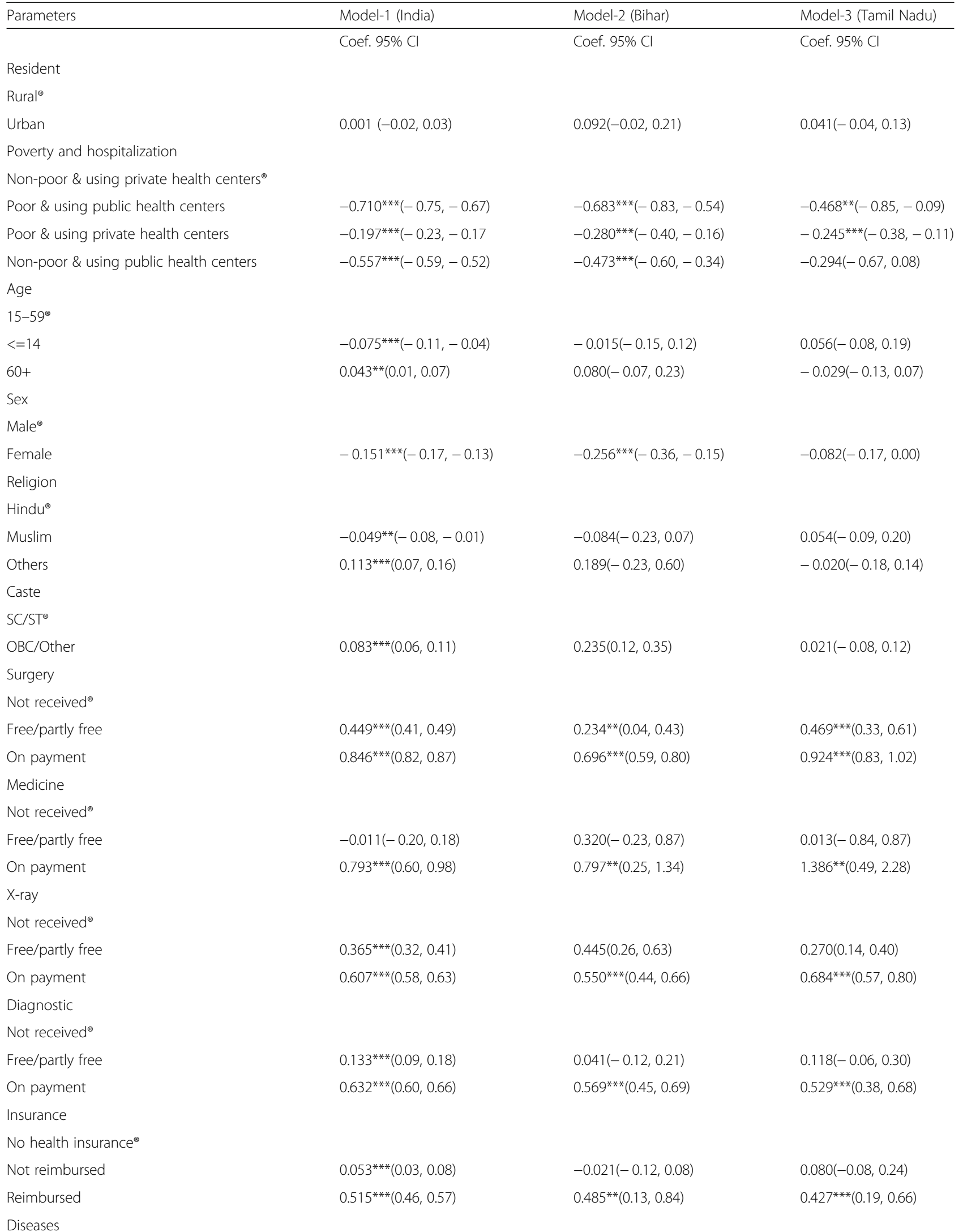


Table 7 Result of log-linear regression model on cost of hospitalization in India, Bihar and Tamil Nadu (Continued)

\begin{tabular}{llll}
\hline Parameters & Model-1 (India) & Model-2 (Bihar) & Model-3 (Tamil Nadu) \\
\hline Cancer & & & $-1.360^{* * *}(-1.85,-0.87)$ \\
Bone disease & $-0.843^{* * *}(-0.96,-0.73)$ & $-1.629^{* * *}(-2.28,-0.98)$ & $-0.409(-0.82,0.00)$ \\
Diabetes & $-0.875^{* * *}(-1.00,-0.75)$ & $-1.804^{* * *}(-2.30,-1.31)$ & $-0.602(-0.82,0.01)$ \\
Fever & $-1.098^{* * *}(-1.20,-0.99)$ & $-1.588^{* * *}(-2.21,-0.97)$ & $-0.555^{* *}(-1.08,-0.03)$ \\
High Blood Pressure & $-1.086^{* * *}(-1.21,-0.96)$ & $-1.606^{* * *}(-2.07,-1.15)$ & $-0.426^{* *}(-0.82,-0.04)$ \\
Accident & $-0.899^{* * *}(-1.00,-0.80)$ & $-1.472^{* * *}(-2.03,-0.92)$ & $0.120(-0.34,0.58)$ \\
Jaundice & $-0.681^{* * *}(-0.80,-0.56)$ & $-1.592^{* * *}(-2.10,-1.09)$ & $-0.487^{* *}(-0.91,-0.06)$ \\
Respiratory Diseases & $-0.960^{* * *}(-1.07,-0.85)$ & $-0.913^{* * *}(-1.42,0.41)$ & $0.043(-0.36,0.45)$ \\
Heart Diseases & $-0.446(-0.55,-0.34)$ & $-2.062^{* * *}(-2.54,-1.58)$ & $-1.440^{* * *}(-1.83,-1.05)$ \\
Eye Diseases & $-1.664^{* * *}(-1.55,-2.062)$ & $-1.685^{* *}(-2.22,-1.16)$ & $-0.400(-1.02,0.22)$ \\
Tuberculosis & $-0.683^{* *}(-0.83,-0.56)$ & $-1.158^{* * *}(-1.67,-0.64)$ & $-0.328(-0.84,0.18)$ \\
Blood disease & $-0.754^{* * *}(-0.88,-0.62)$ & $-1.124^{* * *}(-1.63,-0.62)$ & $-0.120(-0.55,0.31)$ \\
Neurological & $-0.609^{* * *}(-0.72,-0.50)$ & $-1.641^{* * *}(-2.09,-1.19)$ & $-0.293(-0.68,0.09)$ \\
Others & $-0.982^{* * *}(-1.08,-0.88)$ & $8.977^{* * *}(8.25,9.71)$ & $7.390^{* * *}(6.39,8.39)$ \\
Constant & $8.446^{* * *}(8.23,8.66)$ & &
\end{tabular}

***p $<0.001,{ }^{* *} p<0.01,{ }^{*} p<0.05$. Reference category. Cl Confidence Interval

centers was highest in Delhi followed by Assam and lowest in Jharkhand followed by Gujarat.

Fourth, we found large variation in components of CHPE in India. For the poor using public health centers in India, the share of doctor's fees account 7\%, medicine $38 \%$, diagnostic tests $14 \%$ and bed $3 \%$. The proportion was much lower in Tamil Nadu than in Bihar. For example, in Tamil Nadu 4\% of CHPE was spent on medicine compared to $45 \%$ in Bihar. Similarly, for the poor who used public health centers in Bihar, 7\% of CHPE was spent on doctor's fee, $10 \%$ spent on diagnostic tests and $3 \%$ on bed charge. In the case of Tamil Nadu, $1 \%$ of CHPE was spent on doctor's fee and $5 \%$ spent on diagnostic tests. Fifth, the variations in the supply side factors such as availability of health facilities, doctors, paramedical, nurses, beds and medicine were large across the states of India. Doctor per 1000 population was the lowest in poorer states Bihar (1.8) and Uttar Pradesh (2.3) and highest in Kerala (8.5) [58]. Sixth, multivariate analysis suggests that the composite variables of poverty and utilization of health care centers were significant predictors of health spending in India. Poor people using public health centers in the state of Tamil Nadu spent less than those in Bihar, controlling for socio-economic correlates.

Our findings suggest large variations in utilization and OOPE on hospitalization among the poor in states of India. These findings are consistent with literature [47, 59-62]. We provide some plausible explanations. Public health centers continues to be the mainstay of health services for the poor while rich people preferring to use private health services $[63,64]$. This is due to the higher ability to pay for health services among the non-poor, health system of the state and access to health insurance I reimbursement mechanism. Health is a state subject and the state government provide preventive, promotive and curative services. Studies have found that due to low quality of care, long waiting time, distance to health centers, and lack of availability of trained professionals in public health centers, people preferred to use private health centers in the poorer states of India $[65,66]$. It may be mentioned that the central and state government has introduced various financial protection schemes for the poor and needy. The most prominent was Rashtriya Swasthya Bima Yojana (RSBY) introduced in 2008 specifically for the households living below the poverty line. Evaluative studies suggest that the RSBY has increased the utilization of public health services but the effect on OOPE was inclusive [17, 38, 43, 61, 67]. A number of schemes were launched by some states in India to provide health insurance to the poor and needy. These include the Chief Minister Comprehensive Health Insurance Schemes (CMCHIS) in Tamil Nadu, Rajiv Aarogyasri schemes in Andhra Pradesh and Telangana, Karunya health insurance schemes in Kerala, Mukhyamantri Amrutam in Gujarat, mahatma Jyotiba Phule Jan Arogya Joyana in Maharashtra, and Yashasvini and Vajpayee Arogyasree in Karnataka.

The CMCHIS schemes in Tamil Nadu are primarily intended for the poor to ensure that they get quality medical services for major ailments. These schemes covered costs up to ₹5 lacs including quality medical and surgical treatment in public and private health centers. Moreover, the relative allocation of state budget on 
health, and allocation within the state budget might be resulting in low OOPE for the public health centers users in Tamil Nadu. Besides publicly funded health insurance schemes, studies also suggest that good public health care infrastructure, distribution of free medicines, and health insurance for formal sector employees may be the other reasons for low OOPE in Tamil Nadu [68]. Similarly, in 2009, the Mukhya Mantri Jeevan Rakhsha Kosh was implemented even in the poorer state of Rajasthan that provided insurance coverage up to ₹5 lacs. Literature suggests that large inter-state variations in health spending $[26,61]$ was due to the limited effect of public funded health insurance (PFHI) schemes, particularly for the poor $[43,67,69]$. Furthermore, the shortfall of health infrastructure in public health centers, way below the prescribed norms in most of the poorer states in India, might be leading to high OOPE in poorer states. For instance, the number of beds per one lakh population is low in the poorer states like Bihar and high in developed states like Delhi and Kerala. There is evidence in developing country that the burden of health care increases with the increase in distance between home and health centers [7].

Recently, the Government of India has introduced the Ayushman Bharat, the largest ever health insurance scheme in the country. The program intended to provide financial protection to the bottom $40 \%$ of the population. The National Health Policy-2017 is also aimed to increase central government spending up to $2.5 \%$, reduce medical impoverishment and reduce inequality in health spending by 2025. However, the effect of Ayushman Bharat could not be assessed due to data limitations. Second, data on health infrastructure were not collected in the NSS survey and could not be analyzed. Establishing from availability of health infrastructure from other sources could not be carried out due to time constraint.

\section{Conclusion}

This study concludes that the poor people in poorer states have not benefited adequately from public health care services and are not protected against unanticipated health care costs. Low public health investment, poor public health infrastructures, non-availability of medicines and diagnosis tests and user fees are the main reasons for the high inter-state variations of OOPE in India. Increasing public spending, effective management of public health centers, effective implementation of state sponsored health insurance schemes, provisioning of medicines and diagnostic test at public health centers of poorer states can reduce inter-state variations of OOPE in India. Some of the best practices of health system within the country, as illustrated by Tamil Nadu, may be adopted in the poor performing states to reduce interstate variations in health spending among the poor.

\section{Additional files}

Additional file 1: Appendix 1. State variations in hospitalization (\%) in public and private health centers by broad disease in India, 2014 (docx $15 \mathrm{~kb})$. (DOCX $14 \mathrm{~kb})$

Additional file 2: Appendix 2. Mean out-of-pocket expenditure on cost of hospitalization (₹) by broad disease in public and private health centers of India, 2014 (docx 17 kb). (DOCX 15 kb)

Additional file 3: Appendix 3. Percentage share of direct and indirect cost of hospitalization by poverty and type of health care centers among major states in India, 2014 (docx 16 kb). (DOCX 16 kb)

Additional file 4: Appendix 4. Marginal effect and 95\% Confidence Interval (Cl) of hospitalization cost per episode in India, Bihar and Tamil Nadu, 2014. (DOCX 15 kb)

\section{Abbreviations}

CDs: Communicable diseases; CHC: Community health center; CHPE: Cost of hospitalization per episode; CHS: Catastrophic health spending;

Cl: Confidence Interval; CMCHIS: Chief minister comprehensive health insurance schemes; DH: District hospital; DLHS: District level households and facility survey; EAGs: Empowered action group states; Exp: exponentiation; GDP: Gross domestic product; ICSSR: Indian council of social science research; IIPS: International institute for population sciences; IPHS: Indian public health standard; MoHFW: Ministry of health and family welfare; MPCE: Monthly per capita expenditure; NCDs: Non-communicable diseases; NSS: National sample survey; NSSO: National sample survey organization; OBC: Other backward classes; OOPE: Out-of-pocket expenditure;

PFHI: Publicly funded health insurance; PHC: Primary health center; RSBY: Rashtriya swasthya bima yojana; SC: Sub center; SC/ST: Schedule caste/ Schedule tribe; SDGs: Sustainable development goals; UHC: Universal health coverage

\section{Acknowledgements}

The authors acknowledge the helpful comments and suggestions by the Editor and the reviewers of this paper with a huge gratitude. Authors thanks to Pijush Kanti Khan, Ansul Kastor and Basant Panda for their needful support and suggestion during revision of the manuscript.

\section{Authors' contributions}

$A D$ and SKM conceptualized and designed the study. AD reviewed the literature for relevant data and documentation. AD compiled the data and performed the analysis. Both authors prepared the manuscript. SKM mentored, and extensively revised the manuscript. The manuscript is part of AD's Post-doctoral research work. Both the authors read and approved the final manuscript.

\section{Funding}

The study did not receive any funding or grant to conduct this particular research. This is an independent work conducted by the authors.

\section{Availability of data and materials}

NSS data used in this study for analysis is publicly available and unit level data could be obtained upon a data request through http://www. icssrdataservice.in/datarepository/index.php/catalog/107, subject to nonprofit and academic interest only. DLHS-4 data used in this study is also publicly available and unit level data could be accessed on a data request from http://rchiips.org/DLHS-4.html. Availability of public health institutions, bed per 1 lacs population, health worker per 1000 population taken from Family Welfare Statistics in India through https://mohfw.gov.in/documents/staistics which is publicly available for all. In another case, the corresponding author of this paper may contacted for data.

\section{Ethics approval and consent to participate}

Health survey data used in this study has been collected by National Sample Survey Organization and DLHS data collected by International Institute for Population Sciences for India which is publicly available and with no access to personal identifiers. 


\section{Consent for publication}

Not applicable.

\section{Competing interests}

The authors declare that they have no competing interests..

\section{Author details}

'International Institute for Population Sciences, Govandi Station Road, Deonar, Mumbai, Maharashtra 400088, India. ${ }^{2}$ Department of Fertility Studies, International Institute for Population Sciences, Govandi Station Road, Deonar, Mumbai 400088, India.

Received: 31 December 2018 Accepted: 19 July 2019

Published online: 30 July 2019

\section{References}

1. WHO. Health systems financing: The path to universal coverage. World Health Organization. 2010

2. WHO. World health statistics: monitoring health for the SDGs. 2018. [http:// apps.who.int/iris/bitstream/handle/10665/272596/9789241565585-eng. pdf?ua=1]. Accessed 20 Jan 2019.

3. van Doorslaer E, O'Donnell O, Rannan-Eliya RP, Somanathan A, Adhikari SR, Garg CC, et al. Effect of payments for health care on poverty estimates in 11 countries in Asia: an analysis of household survey data. Lancet. 2006; 368(9544):1357-64.

4. O'Donnell O, van Doorslaer E, Rannan-Eliya RP, Somanathan A, Adhikari SR, Harbianto D, et al. The incidence of public spending on healthcare: comparative evidence from Asia. World Bank Econ Rev. 2007;21(1):93-123.

5. Wagstaff A, Flores G, Hsu J, Smitz MF, Chepynoga K, Buisman LR, et al. Progress on catastrophic health spending in 133 countries: a retrospective observational study. Lancet Glob Heal. 2018;6(2):e169-79.

6. Li Y, Wu Q, Xu L, Legge D, Hao Y, Gao L, et al. Factors affecting catastrophic health expenditure and impoverishment from medical expenses in China: policy implications of universal health insurance. Bull World Health Organ. 2012;90(9):664-71.

7. Kumara AS, Samaratunge R. Patterns and determinants of out-of-pocket health care expenditure in Sri Lanka: evidence from household surveys. Health Policy Plan. 2016;31(8):970-83.

8. Molla AA, Chi C, Mondaca ALN. Predictors of high out-of-pocket healthcare expenditure: an analysis using Bangladesh household income and expenditure survey, 2010. BMC Health Serv Res. 2017;17(1):94.

9. Pandey A, Ploubidis GB, Clarke L, Dandona L. Trends in catastrophic health expenditure in India: 1993 to 2014. Bull World Health Organ. 2018;96(1):18-28.

10. Berki SE. A look at catastrophic medical expenses and the poor. Health Aff. 1986;5(4):138-45.

11. Xu K, Evans DB, Kawabata K, Zeramdini R, Klavus J, Murray CJ. Household catastrophic health expenditure: a multicountry analysis. Lancet. 2003; 362(9378):111-7.

12. McIntyre D, Thiede M, Dahlgren G, Whitehead M. What are the economic consequences for households of illness and of paying for health care in low- and middle-income country contexts? Soc Sci Med. 2006;62(4):858-65.

13. Leive A, Xu K. Coping with out-of-pocket health payments: empirical evidence from 15 African countries. Bull World Health Organ. 2008;86:849-856C.

14. Mahal A, Karan A, Engelgau M. The economic implications of noncommunicable disease for India. 2010. https://openknowledge.worldbank. org/handle/10986/13649. Accessed 10 May 2018.

15. Xu K, Evans DB, Carrin G, Aguilar-Rivera AM, Musgrove P, Evans T. Protecting households from catastrophic health spending. Health Aff. 2007;26(4):972-83.

16. Xie $X$, Wu Q, Hao Y, Yin H, Fu W, Ning N, et al. Identifying determinants of socioeconomic inequality in health service utilization among patients with chronic non-communicable diseases in China. PLoS One. 2014;9(6):e100231.

17. Balarajan $Y$, Selvaraj S, Subramanian S. Health care and equity in India. Lancet. 2011;377(9764):505-15.

18. UNDP. Background on the goals. United Nation. 2015. [http://www.undp. org/content/undp/en/home/sustainable-development-goals.html]. Accessed 10 May 2018.

19. Arsenijevic J, Pavlova M, Groot W. Measuring the catastrophic and impoverishing effect of household health care spending in Serbia. Soc Sci Med. 2013;78:17-25.
20. Leive A, Xu K. Coping with out-of-pocket health payments: empirical evidence from 15 African countries. Bull World Health Organ. 2008;86(11): 849-56.

21. Bhojani U, Thriveni B, Devadasan R, Munegowda C, Devadasan N, Kolsteren $P$, et al. Out-of-pocket healthcare payments on chronic conditions impoverish urban poor in Bangalore, India. BMC Public Health. 2012;12(1):990.

22. Karan A, Selvaraj S, Mahal A. Moving to universal coverage? Trends in the burden of out-of-pocket payments for health care across social groups in India, 1999-2000 to 2011-12. PLoS One. 2014;9(8):e105162.

23. Alam K, Mahal A. The economic burden of angina on households in South Asia. BMC Public Health. 2014;14(1):179.

24. Pallegedara A. Impacts of chronic non-communicable diseases on households' out-of-pocket healthcare expenditures in Sri Lanka. Int J Heal Econ Manag. 2018;18(3):301-19.

25. Garg CC, Karan AK. Reducing out-of-pocket expenditures to reduce poverty: a disaggregated analysis at rural-urban and state level in India. Health Policy Plan. 2009;24(2):116-28.

26. Ghosh S. Catastrophic payments and impoverishment due to out-of-pocket health spending. Econ Polit Wkly. 2011;46(47):63-70.

27. Mohanty SK, Kim R, Khan PK, Subramanian SV. Geographic variation in household and catastrophic health spending in India: assessing the relative importance of villages, districts, and states, 2011-2012. Milbank Q. 2018; 96(1):167-206.

28. Carrin G, Mathauer I, Xu K, Evans DB. Universal coverage of health services: tailoring its implementation. Bull World Health Organ. 2008; 86(11):857-63.

29. Limwattananon S, Prakongsai P, Tangcharoensathien V, Limwattananon S, Prakongsai $P$. The equity impact of universal coverage: health care finance, catastrophic health expenditure, utilization and government subsidies in Thailand BT - Consortium for Research on Equity in Health Systems (CREHS) Report. Report of the Consortium for Research on Equitable Health Systems (CREHS). 2011. http://www.crehs.Ishtm.ac.uk/thai_biafia_19jul.pdf. Accessed 3 June 2018.

30. Zhang L, Liu N. Health reform and out-of-pocket payments: lessons from China. Health Policy Plan. 2014;29(2):217-26.

31. Levesque J-F, Haddad S, Narayana D, Fournier P. Outpatient care utilization in urban Kerala. India Health Policy Plan. 2006;21(4):289-301.

32. Kastor A, Mohanty SK. Disease and age pattern of hospitalisation and associated costs in India: 1995-2014. BMJ Open. 2018;8(1):e016990.

33. Peters DH. Better health systems for India's poor : findings, analysis, and options. World Bank; 2002.

34. Mohanty SK, Kastor A. Out-of-pocket expenditure and catastrophic health spending on maternal care in public and private health centres in India: a comparative study of pre and post national health mission period. Health Econ Rev. 2017;7(1):31

35. MOHFW. National health accounts estimates for India. 2017. https://mohfw. gov.in/sites/default/files/National\%20Health\%20Accounts\%20Estimates\%2 OReport\%202014-15.pdf]. Accessed 3 June 2018.

36. MoHFW. Health insurance expenditure in India. 2016. Available from: https://mohfw.gov.in/sites/default/files/6691590451489562855.pdf. Accessed 4 June 2018.

37. Hooda SK. Out-of-pocket payments for healthcare in India. J Health Manag. 2017;19(1):1-15.

38. Karan A, Yip W, Mahal A. Extending health insurance to the poor in India: an impact evaluation of rashtriya swasthya Bima yojana on out of pocket spending for healthcare. Soc Sci Med. 2017;181:83-92.

39. Berman P, Ahuja R, Bhandari L. The impoverishing effect of healthcare payments in India : new methodology and findings. Econ Politcal Wkly. 2010;45(16):65-71.

40. Mukherjee S, Haddad S, Narayana D. Social class related inequalities in household health expenditure and economic burden: evidence from Kerala, South India. Int J Equity Health. 2011;10(1):1.

41. Singh $P$, Kumar $V$. The rising burden of healthcare expenditure in India: a poverty nexus. Soc Indic Res. 2017;133(2):741-62.

42. Bajpai V, Singh N, Sardana H, Kumari S, Vettiyil B, Saraya A. Economic and social impact of out-of-pocket expenditure on households of patients attending public hospitals. Natl Med J India. 2017;30(1):15-20.

43. Selvaraj S, Karan AK. Why publicly-financed health insurance schemes are ineffective in providing financial risk protection. Econ Polit Wkly. 2012;47(11):60-8. 
44. Ghosh S. Publicly financed health insurance for the poor. Econ Polit Wkly. 2014; XIIX(43):93-99.

45. Joe W, Perkins JM, Kumar S, Rajpal S, Subramanian SV. Institutional delivery in India, 2004-14: unravelling the equity-enhancing contributions of the public sector. Health Policy Plan. 2018;33(5):645-53.

46. Hooda SK. Out-of-pocket payments for healthcare in India: who have affected the most and why? J Health Manag. 2017;19(1):1-15.

47. Chandra R, Singh A, Mukherjee S, Delhi N, Health G, Unit SC. A disaggregated analysis of change in household out-of-pocket expenditure on healthcare in India, 1995-2004. 2013;3(1):257-66.

48. Gupta I, Chowdhury S, Prinja S, Trivedi M. Out-of-pocket spending on outpatient care in India : assessment and options based on results from a district level survey. PLoS One. 2016;11(11):e0166775.

49. Deogaonkar M. Socio-economic inequality and its effect on healthcare delivery in India: inequality and healthcare. J Sociol. 2004:8:1-12.

50. Subramanian SV, Nandy S, Irving M, Gordon D, Lambert H, Davey SG. The mortality divide in India: the differential contributions of gender, caste, and standard of living across the life course. Am J Public Health. 2006;96(5):818-25.

51. Mohanty SK. Multiple deprivations and maternal care in India. Int Perspect Sex Reprod Health. 2012;38(1):6-14.

52. Ladusingh L, Pandey A. Health expenditure and impoverishment in India. J Health Manag. 2013;15(1):57-74.

53. NSSO. Health in India. 2015. National sample survey organization. [http//mospi.nic. in/sites/default/files/publication reports/nss_rep574.pdff. Accessed 10 May 2018.

54. Ladusingh L, Pandey A. The high cost of dying. Econ Politcal Wkly. 2013; 48(11):44-9.

55. DLHS-4. District level household \& facility survey (DLHS-4). International Institute for Population Sciences. 2014. [http://rchiips.org/DLHS-4.html]. Accessed 17 Mar 2019.

56. Planning comission. Report of the expert group to review the methodology for measurment of poverty. 2014. [http://planningcommission.nic.in/reports/ genrep/pov_rep0707.pdf]. Accessed 14 July 2018.

57. Binnendijk E, Koren R, Dror DM. Hardship financing of healthcare among rural poor in Orissa, India Hardship financing of healthcare among rural poor in Orissa, India. BMC Health Serv Res. 2012;12(1):23.

58. Motkuri V, Mishra US. Human resources in healthcare and health outcomes in India; 2018.

59. Chaudhuri A. Socio-economic inequity in health care utilization \&amp; expenditures in richer states in India. Indian J Med Res. 2012;136(3):368-9.

60. Pandey A, Ploubidis GB, Clarke L, Dandona L. Horizontal inequity in outpatient care use and untreated morbidity: evidence from nationwide surveys in India between 1995 and 2014. Health Policy Plan. 2017;32(7):969-79.

61. Selvaraj S, Farooqui HH, Karan A. Quantifying the financial burden of households' out-of-pocket payments on medicines in India: a repeated cross-sectional analysis of national sample survey data, 1994-2014. BMJ Open. 2018;8(5):e018020.

62. Mohanty SK, Panda B, Khan PK, Behera P. Out-of-pocket expenditure and correlates of caesarean births in public and private health centres in India. Soc Sci Med. 2019;224:45-57.

63. Prinja $\mathrm{S}$, Kumar MI, Pinto AD, Jan S, Kumar R. Equity in hospital services utilisation in India. Econ Polit Wkly. 2013;48:52-8.

64. Mondal S. Health care services in India: a few questions on equity. Health (Irvine Calif). 2013;5(1):53-61.

65. Sah DC, Kumar Y. Client satisfaction exit interviews: assessing quality of public health institutions through generated feedback. Vikalpa. 2015;40(1):42-61.

66. Das J, Holla A, Mohpal A, Muralidharan K. Quality and accountability in health care delivery: audit-study evidence from primary care in India. Am Econ Rev. 2016;106(12):3765-99.

67. Ghosh S, Gupta ND. Targeting and effects of rashtriya swasthya bima yojana on access to care and financial protection. Econ Polit Wkly. 2017;LII(4):61-70.

68. Mukhopadhyay I, Madras T, Madras T. Tamil Nadu state health account 2013-14. 2017. [https://www.researchgate.net/publication/317493240_ TAMIL_NADU_STATE_HEALTH_ACCOUNTS_2013-14]. Accessed 5 Aug 2018.

69. Ranjan A, Dixit P, Mukhopadhyay I, Thiagarajan S. Effectiveness of government strategies for financial protection against costs of hospitalization care in India. BMC Public Health. 2018;18(1):1-12.

\section{Publisher's Note}

Springer Nature remains neutral with regard to jurisdictional claims in published maps and institutional affiliations.

\section{Ready to submit your research? Choose BMC and benefit from:}

- fast, convenient online submission

- thorough peer review by experienced researchers in your field

- rapid publication on acceptance

- support for research data, including large and complex data types

- gold Open Access which fosters wider collaboration and increased citations

- maximum visibility for your research: over $100 \mathrm{M}$ website views per year

At BMC, research is always in progress.

Learn more biomedcentral.com/submissions 